\title{
Participation and Performance of Women Candidates in the General Elections of India: An Analytical Study (1951-2009)
}

\author{
Ramesh Pandita \\ Baba Ghulam Shah Badshah University, Rajouri, \\ R/o 274-C, Durga Nagar Sect. No I, P/o Roop Nagar, Jammu - 180013, \\ Jammu \& Kashmir, India \\ E-mail address: rameshpandita90@gmail.com
}

\begin{abstract}
Participation of women in the electoral process of India as contestants has been very abysmal since the inception of the electoral process of the country. Present study has been conceived in view of the demands raised by various political parties and different women organizations about introducing and passing of women's reservation bill in the parliament so as to secure at least $33 \%$ seats for women candidates across the country. In the present study attempt has been made to see how far women candidates have been given representation by national and state level political parties during all the general elections held in India since independence. The other areas covered in the study include the distribution of political parties during all the general elections held, female candidate fielded by parties in proportion to male candidates, their success rate, votes secured, forfeited deposits etc. the study is purely based on secondary data, retrieved from the official website of the Election Commission of India on October 21, 2013. The multiparty system in India has somewhere become the areas of concern, which in fact has heralded an era of coalition politics in country, where the number has grown exponentially and as of now more than 2000 political parties stand registered with the Election commission of India. On average mere $6.90 \%$ women candidates have been chosen to parliament during each general election, while as on average $4.49 \%$ women contestants have been fielded in each general election. Scenario of state political parties is more worrisome and in case of independent contestants the situation is quite displeasing.
\end{abstract}

Keywords: India; Electoral Process; General Elections; Women Contestants; Women Participation; Multi Party System; Voter Turnout

\section{INTRODUCTION}

Women empowerment has always been the top agenda of the most of the global democracies. Even the developed nations like US, Japan, or even the European nations have not yet overcome this curse. The developed nations have been equally fighting this issue despite having empowered women in many ways.

Various NGO's and agencies at international level have been putting in every possible effort to empower women so as to have equal opportunities for both men and women. Taking further the cause of fight against gender inequality, favoring the concept of equal opportunities for women in public life, 163 nation states in 1979 came together to sing Convention on the 
Elimination of All Forms of Discrimination against Women (CEDAW ${ }^{[1]}$. On the similar lines UN Platform for Action (1995) explicitly stands for 50-50 gender balance in all areas and politics being one of them. Most of the democracies across the world uphold this fact that political empowerment of women would empower women in other social spheres.

In Indian polity it was Sarojini Naidu who led a women delegation with the demand of voting rights to women and called on committee on December 18, 1917, which was duly backed by the then national political stalwarts like, Bal Gangadhar Tilak, Vithalbai Patel and Mohammed Ali Jinnah (Visalakshi Menon, p. 113) ${ }^{[2]}$. Although India has grown over 67 years old since it attaining independence, but if we take a look at the participation and performance figures of the women contestants in the general elections of India, there figures give us every reason to believe that situation on ground has not changed at all and if we count it as of having moved from bad to worse it won't be inappropriate.

The present study is totally confined to women participation in the polity of India since the inception of the electoral process of the country. India is a socialist secular democratic republic with a population of over 1.2 billion where against 623 million registered males there are 586 million registered females with sex ratio of 940 females to per 1000 males which at the time of independence were 946 females $^{[3]}$. The sex ration in Indian population reached to its lowest ebb of 927 females to per 1000 males when it came to fore during the 1991 census. Since then the situation has improved considerably but still far less than to its natural sex ratio. The above figures somewhere reflect the social standing of Indian women, which by no means is enjoying it at par with males. These figures do somewhere indicate the reasons, need and importance thereof in Indian social setup to have reservation for women in Indian political structure, resulting in to introduction of women's reservations bill in parliament so as to ensure $33 \%$ reservation for women candidates. Although the bill has been already passed in the Rajya Sabha (Upper House or House of the Council) in 2010 but is still laying for the approval of the Lok Sabha (Lower House or the House of the People), where it is yet to be tabled.

India is a very diverse country having diversity almost at every front, be it social, cultural, racial, religious, geographical, linguistic or even ethnic. This diversity has equally helped in furthering the society to become more gender bias. If one section of Indian society upholds and believes in giving equal rights and equal opportunities to women folk the other section on the contrary believes in rating women as a second rate human being, who is more a sex slave, a child bearing machine, who most of the time is confined to kitchen and in raring and caring of children and cattle.

Constitution of India recognizes both men and women equally but this gets itself refuted by the fact that the need arises for agencies to enforce such provisions be it in the form of introduction of women's reservation bill or other time to time constitutional provisions made to secure women rights in almost every sphere of their day to day life. Under this pluralistic social setup of India, where women from one strata enjoys everything at par with men but from other strata she is deprived of all such privileges even after the 67 years of India's independence, the Indian women is still somewhere reeling under the slavery of their own male relatives.

Post 1947 India is being seen as modern and progressive and has emerged as a major power in South Asia, lying north of the equator between $6^{\circ} 44^{\prime}$ and $35^{\circ} 30^{\prime}$ north latitude and $68^{\circ} 7^{\prime}$ and $97^{\circ} 25^{\prime}$ east longitude ${ }^{[4]}$. Formation of Election Commission as a constitutional body is vested with superintendence to conduct free and fair elections to parliament, state legislature, to the offices of President and Vice-President. 
The commission came into existence on January 25, 1950 and conducted first general elections in 1951 and thereon there is no looking back and the commission is all set to conduct the $16^{\text {th }}$ general election to parliament in the year 2014 .

In 2014 general elections it will be interesting to see how far main stream political parties will give representation to women candidates or would prove no way different from the earlier elections and the promises made by parties will prove mere hollow claims of pushing for the passage of bill only. Needless to make mention about India having the bicameral structure, consisting of President and the two houses of the parliament, known as Rajya Sabha and the Lok Sabha ${ }^{[5]}$.

The present study is an analysis of all the general elections held in India since 1951 as per the objectives of the study. To undertake the study data has been retrieved from the official website of the Election Commissioner of India on October 21, 2013 $3^{[6]}$, accessible at http://eci.gov.in/eci_main1/ElectionStatistics.aspx.

The present study is an overview of all the general elections held in India since its attaining independence. Every attempt has been made to put forth the analyzed data in most convenient and easy to understand way. Most of the analysis has been carried out as per the objectives of the study; however during the course of analysis all such aspects have been put forth which serve the purpose of present study in one or the other way.

\section{COMPOSITION OF INDIAN PARLIAMENT}

The Structure of Indian Parliament as laid down in country's constitution is bicameral in nature, consisting of President and the two houses Rajya Sabha (the upper house or the Council of States) and the Lok Sabha (the lower house or the House of the People) ${ }^{[7]}$.

So far India has gone through 15 general elections, held during the year 1951, 1957, $1962,1967,1972,1977,1980,1984,1989,1991,1996,1998,1999,2004$ and $2009^{[8]}$ and the sixteenth general elections are due to be held in the year 2014.

Rajya Sabha, consists of 250 members, 12 of whom are nominated by President, having special knowledge or practical experience in areas like, Literature, Science, Art or Social Services and rest are from states and union territories in proportion its population elected by the elected members of the Legislative Assembly through single transferable vote system. The minimum age required to be a member of the house is 30 years.

Lok Sabha on the other hand has a maximum strength of 552 members of which 530 represent state, 20 represent Union Territories and two members of Anglo-Indian Community are nominated by the president, if the community is not adequately represented in the house. The present Lok Sabha consists of 545 members including two nominated members and the minimum age to be the member of the Lok Sabha as fixed under the constitution is 25 years. Members of Lok Sabha are chosen by people directly through the electoral process for a period of five years, unless sooner dissolved.

\section{REVIEW OF LITERATURE}

Researchers all across the globe be it from economics, sociology, education, politics or any other socio science have been putting in every effort to analyze the reasons for second rated treatment women most of the time met. Politics is one such grey area where women has not 
made any significant presence, this is also being seen as a reason because of which women suffer at other fronts and political empowerment of women is being seen as formidable leap in the mankind to overcome the women suppression problem. Given these fact men in politics have been working in the direction of women empowerment and giving political reservations to women is one such broad area which is being discussed and debated across all the democracies of the world.

Richard et al (2011) ${ }^{[9]}$ in their study discussed about the professional life of women in America which is more progressive and developed when compared to the rest of the world and found that less than $17 \%$ of the American women hold elected offices. The study further revealed that 2010 elections showed decrease in the male female ration in congress. the same study revealed that $78 \%$ women representatives are of the view that it is difficult for women to be elected over men for existing gender bias which $57 \%$ male representatives agreed to. The researchers are of the view that the existing gender gap cannot be overcome by striving for similar professional credentials, economic autonomy and political experience alone.

As per the estimate of the United Nations Development Programme (2002) ${ }^{[10]}$ representation of women in elected public offices is abysmal, as women represent less than one-tenth of world's cabinet ministers and one-fifth of sub-ministerial positions. The estimate report further revealed that out of 193 nations only nine women were at the pinnacle position and only 39 nation states have elected women as a President or Prime Minister.

As per the report on the Cook Islands parliamentary elections (2004) ${ }^{[11]}$, there was high percentage of incumbency of the dominant parties in cook Islands Parliamentary Elections. Out of the 58 sitting members less than 10 were women. The report in its observation also made clear that, how two dominant political parties fielded only two women candidates each, which reflect that how few women have only achieved political status since independence.

Philips (1998) ${ }^{[12]}$ is of the view that how elected women representatives actually act as group towards the empowerment of women. Women legislators play a pivotal role in raising the distinctive and priority issues upholds Carroll $(2001)^{[13]}$. Pitkin (1967 $)^{[14]}$ in his study argued that elected representatives should reflect the politically relevant electoral cleavages and gender representation should be given due heed. Inglehart and Norris $(2003)^{[15]}$ are of the view that most of the parliaments across the established democracies of globe fail to reflect the proportion of women electorate.

At the same time we do have recorded instances of women elected representatives performing if not better but equally well to their male counterparts. Bergqvist et al., (1999) ${ }^{[16]}$ in their study on Nordic nations about the women representatives in parliament, which constituted around $40 \%$ of MP's in the lower house and were doing best. Sweden in 1950 represented $10 \%$ women representatives in its parliament and this figure rose to $43 \%$ by 1999 . The study further deliberated upon how women in countries like Qatar, Saudi Arabia, Oman and UAE are barred by law to be elected to parliaments of their respective countries.

Mhatre Minal (2009) ${ }^{[17]}$ undertook a study on the women's political participation in Maharashtra and found that from election to election there is increase in the women contestant but the percentage of success is not that encouraging. This gets better established by the fact that in 1952 out of 16 women contestant 5 succeeded, while as in 2004 out of 157 women contestants only 12 succeeded. A maximum of 19 candidates successes in 1980 when only 47 candidates contested the elections and in 1995 when a maximum of 247 women candidates were in fray but only 11 succeeded. The researcher also observed that majority of the women contestants are independents and the representation to women candidates by national parties is abysmal. 
Reynolds $(2005)^{[18]}$ in his study talked about the reservation policy of women in politics, as it will ensure participation of women in politics and the Dutch Parliament need to introduce such policy where by those reserved seats should only be contested by women candidates.

The policy is already taking shape in India where women's reservation bill is to be passed in Lok Sabha and same is being introduced in New Zealand for women representation in Maoris. The practice is already vogue in Africa, South Asia, and in some Muslim nations like, Morocco, Afghanistan, Bangladesh, Pakistan, Botswana, Taiwan, Lesotho, Tanzania etc. Tinkar (2004) $)^{[19]}$ argued about this kind of arrangement, as same can never guarantee the women empowerment as it will be merely arrangement to appease the women to sideline them.

\section{OBJECTIVES OF THE STUDY}

- To study and understand the level of participation and performance of women contestants during all the general elections held in India since independence

- To assess the representation so far give to women contestants by national political parties of India who seem to be vigorously pushing for women's reservation bill.

- To quantify the participation of women elector in general election of India and the percentage of vote's women contestants had been able to bag.

- The other aspects undertaken in the study include, growth of political parties since the first general elections, growth of women contestants from each corresponding election, success percentage and women representatives in each general election, deposits forfeited by women candidates on election to election basis and many other similar aspects.

\section{METHODOLOGY AND SCOPE}

To undertake the present study data was retrieved from the official website of the Election Commission of India on October 21, 2013, accessible at: http://eci.gov.in/eci_main1/ElectionStatistics.aspx.

Given the objectives of the study, the data retrieved was totally in raw form as such was put to structuration, so as to meet the objectives of the study. There on the data in more helpful sequence was put to analysis by pressing into service various statistical tools and techniques.

The study leaves every scope where by similar studies can be undertaken at individual level in states of the Union of India.

These studies will help develop a broader idea about the areas which are better in women representation and the states which provide just lip services on the introduction of women's reservation bill, and can also help in initiating measures to plug the loopholes in the political system of India, if any.

\section{LIMITATIONS OF THE STUDY}

Upon structuration of data it emerged that the data for the year 1951 and 1971 general elections was not comprehensive, as such posed difficulty in making exact calculations. Similarly while assessing the distribution of vote share among woman contestants, the data was not available for the elections year 1951, 1962, 1971, 1977, 1984 and 1991. Keeping in view the non-availability of data analysis in such tables has been drawn by excluding these years 
from computation and the average and percentage figures at such places have been drawn for the period where data was available.

\section{DISCUSSION AND DATA ANALYSIS}

Passage of women's reservation bill in the Lok Sabha is still being seen as the biggest hurdle in ensuring socio political empowerment of Indian women folk. National or regional political parties have not so far given any due representation to women candidates during the last fifteen general elections, this as a fact has led to the situation where by introduction and passage of women's reservation bill has become inevitable.

Apart from using statistical tools and techniques, data was equally put to MS Excel format, so as to perform simple expressions like, addition, subtraction, division and drawing percentage etc. percentage at most of the places has been drawn up to two decimal places but wherever warranted same has been drawn beyond two decimal places. At some places figures have also been rounded off either to previous highest or the next higher depending up on the expression if it is below or above the .5 percent.

Table 1. Distribution of Elections and Participation of parties.

\begin{tabular}{|c|c|c|c|c|c|}
\hline Year & Seats & $\begin{array}{c}\text { National } \\
\text { Parties (\%) }\end{array}$ & $\begin{array}{c}\text { State Parties + } \\
\text { Independents } \\
\mathbf{( \% )}\end{array}$ & Total & $\begin{array}{c}\text { Corresponding } \\
\text { Growth (\%) }\end{array}$ \\
\hline 1951 & $\# 489$ & $14(25.92)$ & $40(74.08)$ & 54 & - \\
\hline 1957 & $\# 494$ & $4(25.00)$ & $12(75.00)$ & 16 & $-38(-70.37)$ \\
\hline 1962 & 494 & $6(21.42)$ & $22(78.58)$ & 28 & $12(75.00)$ \\
\hline 1967 & 520 & $7(26.92)$ & $19(73.08)$ & 26 & $-2(-7.14)$ \\
\hline 1971 & 518 & $8(14.81)$ & $46(85.19)$ & 54 & $28(107.69)$ \\
\hline 1977 & 542 & $5(14.28)$ & $30(85.72)$ & 35 & $-19(-35.18)$ \\
\hline 1980 & 529 & $6(16.66)$ & $31(83.34)$ & 36 & $1(2.85)$ \\
\hline 1984 & 514 & $7(20.58)$ & $27(79.42)$ & 34 & $-2(-5.55)$ \\
\hline 1989 & 529 & $8(7.01)$ & $106(92.99)$ & 114 & $80(235.29)$ \\
\hline 1991 & 521 & $9(6.12)$ & $137(93.88)$ & 147 & $33(28.94)$ \\
\hline 1996 & 543 & $8(3.80)$ & $202(96.20)$ & 210 & $63(42.85)$ \\
\hline 1998 & 543 & $7(3.95)$ & $170(96.05)$ & 177 & $-33(-15.71)$ \\
\hline 1999 & 543 & $7(4.11)$ & $163(95.89)$ & 170 & $-7(-3.95)$ \\
\hline 2004 & 543 & $6(2.59)$ & $225(97.41)$ & 231 & $61(35.88)$ \\
\hline 2009 & 543 & $7(1.92)$ & $357(98.08)$ & 364 & $133(57.57)$ \\
\hline Avg & & 7.26 & 105.80 & 113.06 & \\
\hline
\end{tabular}

During the first Lok Sabha elections there were 54 political parties in fray, the number kept on increasing as we move down to 2009 general elections when 364 political parties contested on 543 Lok Sabha seats, a growth of over $574 \%$. On average 7.26 national political parties contested each general election, while as at the same time 105.80 state political parties were in fray in each general election and together on average 113.06 political parties contested each general election in India. 
Table 2. Distribution of Female Candidates fielded Compared to Male and their Success Percentage.

\begin{tabular}{|c|c|c|c|c|c|c|}
\hline \multirow{2}{*}{ Year } & \multicolumn{3}{|c|}{ Candidate Fielded } & \multicolumn{3}{c|}{ Elected \& Share (\%) } \\
\cline { 2 - 7 } & Total & Male (\%) & Female (\%) & Male (\%) & Female (\%) & Total \\
\hline 1951 & $1874^{\wedge}$ & NA & NA & NA & NA & $489^{\wedge}$ \\
\hline 1957 & 1519 & $1474(97.03)$ & $45(2.97)$ & $472(95.54)$ & $22(4.46)$ & 494 \\
\hline 1962 & 1985 & $1919(96.67)$ & $66(3.33)$ & $463(93.72)$ & $31(6.28)$ & 494 \\
\hline 1967 & 2369 & $2302(97.17)$ & $67(2.83)$ & $491(94.42)$ & $29(5.58)$ & 520 \\
\hline 1971 & $2784^{\wedge}$ & NA & NA & NA & NA & $518^{\wedge}$ \\
\hline 1977 & 2439 & $2369(97.12)$ & $70(2.88)$ & $523(96.49)$ & $19(3.51)$ & 542 \\
\hline 1980 & 4629 & $4486(96.91)$ & $143(3.09)$ & $501(96.49)$ & $28(3.51)$ & 529 \\
\hline 1984 & 5312 & $5150(96.95)$ & $162(3.05)$ & $472(91.82)$ & $42(8.18)$ & 514 \\
\hline 1989 & 6160 & $5962(96.78)$ & $198(3.22)$ & $500(94.51)$ & $29(5.49)$ & 529 \\
\hline 1991 & 8668 & $8342(96.23)$ & $326(3.77)$ & $484(92.89)$ & $37(7.11)$ & 521 \\
\hline 1996 & 13952 & $13353(95.70)$ & $599(4.30)$ & $503(92.63)$ & $40(7.37)$ & 543 \\
\hline 1998 & 4750 & $4476(94.23)$ & $274(5.77)$ & $500(92.08)$ & $43(7.92)$ & 543 \\
\hline 1999 & 4648 & $4364(93.88)$ & $284(6.12)$ & $494(90.97)$ & $49(9.03)$ & 543 \\
\hline 2004 & 5435 & $5080(93.46)$ & $355(6.54)$ & $498(91.71)$ & $45(8.29)$ & 543 \\
\hline 2009 & 8070 & $7514(93.11)$ & $556(6.88)$ & $484(89.13)$ & $59(10.87)$ & 543 \\
\hline Avg & 69936 & $66791(5138)^{*}$ & $3145(242)^{*}$ & $6385(491)$ & $473(36)$ & 6858 \\
\hline$\wedge$ & $(5380)^{*}$ & $\#(95.50)$ & $\#(4.50)$ & $\#(93.10)$ & $\#(6.90)$ & \\
\hline
\end{tabular}

$\wedge$-Data inadequately available as such excluded from computation

\# Average percentage of candidates fielded \& succeeded

The above tabulation is a clear reflection of the poor percentage of women candidates fielded during all the general election held in India. A minimum of $2.83 \%$ female candidates were fielded during the year 1967 elections and a maximum of $6.89 \%$ candidates contested 2009 general elections. At the gross national level during all the general elections held in India, of all the candidates who contested general elections in India, on average $4.50 \%$ contestants were woman candidates and $95.50 \%$ male candidates. Tale of the success percentage of women candidates is no way different to that of women candidates fielded. A minimum of $3.51 \%$ women representatives succeeded during the election year of 1977 and 1980 and a maximum $10.87 \%$ during the year 2009. On average $6.90 \%$ women candidates represented electoral of the nation in parliament during each general election while as at the same time $93.10 \%$ male contestants represented Indian electoral in parliament during each general election. 
Table 3. Status of National and State Political Parties and the representation given by them to women candidates.

\begin{tabular}{|c|c|c|c|c|c|c|c|c|}
\hline \multirow{2}{*}{ Year } & \multicolumn{4}{|c|}{ Total Candidates Fielded } & \multicolumn{4}{|c|}{ Women Candidates Fielded \& Share (\%) } \\
\hline & $\mathbf{N P}$ & SP & $\mathbf{I N}$ & Total & NP (\%) & SP (\%) & IN (\%) & Total \\
\hline 1951 & $1217^{\wedge}$ & $124^{\wedge}$ & $355^{\wedge}$ & $1874^{\wedge}$ & NA & NA & NA & NA \\
\hline 1957 & 919 & 119 & 481 & 1519 & $34(3.69)$ & $2(1.68)$ & $9(1.87)$ & $45(2.96)$ \\
\hline 1962 & 1269 & 237 & 479 & 1985 & $52(4.09)$ & $6(2.53)$ & $8(1.67)$ & $66(3.32)$ \\
\hline 1967 & 1342 & 161 & 866 & 2369 & $50(4.34)$ & $7(4.34)$ & $10(1.15)$ & $67(2.82)$ \\
\hline 1971 & $1223^{\wedge}$ & $427^{\wedge}$ & $1134^{\wedge}$ & $2784^{\wedge}$ & NA & NA & NA & NA \\
\hline 1977 & 1060 & 155 & 1224 & 2439 & $41(3.86)$ & $5(3.22)$ & $24(1.96)$ & $70(2.87)$ \\
\hline 1980 & 1541 & 262 & 2826 & 4629 & $77(4.99)$ & $5(1.90)$ & $61(2.15)$ & $143(3.08)$ \\
\hline 1984 & 1244 & 277 & 3791 & 5312 & $63(5.06)$ & $5(1.80)$ & 94 (2.47) & $162(3.04)$ \\
\hline 1989 & 1378 & 1069 & 3713 & 6160 & $87(6.31)$ & $29(2.71)$ & $82(2.20)$ & $198(3.21)$ \\
\hline 1991 & 1822 & 1332 & 5514 & 8668 & $119(6.53)$ & $53(3.97)$ & $154(2.79)$ & $326(2.72)$ \\
\hline 1996 & 1817 & 1499 & 10636 & 13952 & $125(6.87)$ & $50(3.33)$ & $424(3.98)$ & $599(4.29)$ \\
\hline 1998 & 1493 & 1342 & 1915 & 4750 & $107(7.16)$ & $90(6.70)$ & 77 (4.02) & 274 (5.76) \\
\hline 1999 & 1299 & 1404 & 1945 & 4648 & $104(8.00)$ & $102(7.26)$ & $78(4.01)$ & $284(6.11)$ \\
\hline 2004 & 1351 & 1699 & 2385 & 5435 & $110(8.14)$ & $128(7.53)$ & $117(4.90)$ & $355(6.53)$ \\
\hline 2009 & 1623 & 2616 & 3831 & 8070 & $134(8.25)$ & $215(8.21)$ & $207(5.40)$ & $556(6.88)$ \\
\hline Avg & $\begin{array}{c}18158 \\
(1396)^{*}\end{array}$ & $\begin{array}{l}12172 \\
(936)^{*}\end{array}$ & $\begin{array}{c}39606 \\
(3047)^{*}\end{array}$ & $\begin{array}{c}69936 \\
(5379)^{*}\end{array}$ & $\begin{array}{c}1103(85)^{*} \\
\#(6.07)\end{array}$ & $\begin{array}{c}697(54)^{*} \\
\#(5.72)\end{array}$ & $\begin{array}{c}1345 \\
(103)^{*} \\
\#(3.39)\end{array}$ & $\begin{array}{c}3145 \\
(242)^{*} \\
\#(4.49)\end{array}$ \\
\hline
\end{tabular}

$\wedge$-Data inadequately available as such excluded from computation

NP - National Parties, SP- State Parties, IN- Independents, NA-Not Available

* -Average Candidates fielded during each general election.

\# -Average percentage of candidates fielded by parties during each general election.

Although, one can see these days that most of the political parties of the country are crying for introduction and passage of women's reservation bill, but if we see the representation given to women candidates by these parties during the previous general elections, one may get the idea about the true colour of these political parties as most of us may not rely on them given their past. If we have a look at the representation of women candidates from election to election basis then there is increase in the number of women candidates fielded by both national and state level political parties. But once the figures are compared with the subsequent increase in the male candidates fielded from time to time then this increase is not proportionate. Women representation by national parties increased from $3.69 \%$ in 1957 to $8.25 \%$ in 2009 and the average percentage of women representation during all the election by national parties remained at $6.07 \%$. Scenario of state level political parties is no way different. Women 
representation by state level political parties rose from $1.68 \%$ in 1957 to $8.21 \%$ in 2009 , while as the average representation during all the general elections by state parties remained at 5.27 $\%$. Similarly independent women candidates grew from $1.87 \%$ to $5.40 \%$ with average representation of $3.39 \%$. While as on the whole, at gross national level women representation during 1957 election was $2.96 \%$ and this share percentage rose to $6.88 \%$ during 2009 election with an average percentage of $4.49 \%$ during all general elections.

Table 4. Success and Share percentage of Women Candidates.

\begin{tabular}{|c|c|c|c|c|c|c|c|c|}
\hline \multirow{2}{*}{ Year } & \multicolumn{3}{|c}{ Women Candidates Fielded \& (\%) } & \multicolumn{3}{c|}{ Women Candidates Elected \& Success (\%) } \\
\cline { 2 - 9 } & NP (\%) & SP (\%) & IN (\%) & Total & NP (\%) & SP (\%) & IN (\%) & Total (\%) \\
\hline $\mathbf{1 9 5 1}$ & NA & NA & NA & NA & NA & NA & NA & NA \\
\hline $\mathbf{1 9 5 7}$ & $34(75.55)$ & $2(4.44)$ & $9(20.00)$ & 45 & $20(58.82)$ & $2(100)$ & $0(0)$ & $22(48.88)$ \\
\hline $\mathbf{1 9 6 2}$ & $52(78.78)$ & $6(9.09)$ & $8(12.12)$ & 66 & $31(59.62)$ & $0(0)$ & $0(0)$ & $31(46.96)$ \\
\hline $\mathbf{1 9 6 7}$ & $50(74.62)$ & $7(10.44)$ & $10(14.92)$ & 67 & $24(48.00)$ & $3(42.85)$ & $2(20.00)$ & $29(43.28)$ \\
\hline $\mathbf{1 9 7 1}$ & NA & NA & NA & NA & NA & NA & NA & NA \\
\hline $\mathbf{1 9 7 7}$ & $41(58.57)$ & $5(7.14)$ & $24(34.28)$ & 70 & $17(41.46)$ & $2(40.00)$ & $0(0)$ & $19(27.14)$ \\
\hline $\mathbf{1 9 8 0}$ & $77(53.84)$ & $5(3.49)$ & $61(42.65)$ & 143 & $27(35.06)$ & $1(20.00)$ & $0(0)$ & $28(19.58)$ \\
\hline $\mathbf{1 9 8 4}$ & $63(38.88)$ & $5(3.08)$ & $94(58.02)$ & 162 & $39(61.90)$ & $3(60.00)$ & $0(0)$ & $42(25.92)$ \\
\hline $\mathbf{1 9 8 9}$ & $87(43.93)$ & $29(14.64)$ & $82(41.41)$ & 198 & $26(29.89)$ & $3(10.34)$ & $0(0)$ & $29(14.64)$ \\
\hline $\mathbf{1 9 9 1}$ & $119(36.50)$ & $53(16.25)$ & $154(47.23)$ & 326 & $35(29.41)$ & $2(3.77)$ & $0(0)$ & $37(11.34)$ \\
\hline $\mathbf{1 9 9 6}$ & $125(20.86)$ & $50(8.34)$ & $424(70.78)$ & 599 & $36(28.80)$ & $4(8.0)$ & $0(0)$ & $40(6.67)$ \\
\hline $\mathbf{1 9 9 8}$ & $107(39.05)$ & $90(32.84)$ & $77(28.10)$ & 274 & $31(28.97)$ & $11(12.22)$ & $1(1.30)$ & $43(15.69)$ \\
\hline $\mathbf{1 9 9 9}$ & $104(36.61)$ & $102(35.91)$ & $78(27.46)$ & 284 & $35(33.65)$ & $13(12.74)$ & $1(1.28)$ & $49(17.25)$ \\
\hline $\mathbf{2 0 0 4}$ & $110(30.98)$ & $128(36.05)$ & $117(32.95)$ & 355 & $30(27.27)$ & $15(11.71)$ & $0(0)$ & $45(12.67)$ \\
\hline $\mathbf{2 0 0 9}$ & $134(24.10)$ & $215(38.66)$ & $207(37.23)$ & 556 & $43(20.37)$ & $16(7.44)$ & $0(0)$ & $59(10.61)$ \\
\hline $\mathbf{A v g}$ & $1103(85)^{*}$ & $697(54)^{*}$ & $1345(103) *$ & 3145 & $394(30)^{*}$ & $75(6)^{*}$ & $4(0.30)^{*}$ & $473(36)^{*}$ \\
$\#(35.07)$ & $\#(22.16)$ & $\#(42.76)$ & $(100)$ & $\#(35.72)$ & $\#(10.76)$ & $\#(0.29)$ & $\#(15.03)$ \\
\hline
\end{tabular}

NP -National Parties, SP- State Parties, IN- Independents, NA-Not Available

* -Average Candidates fielded during each general election.

\# -Average percentage of candidates fielded by parties during each general election

During the earlier general elections, national parties when compared to state level political parties have still given better representation to women candidates, but the momentum of percentage decreases as we move down towards the 2009 general elections when taken the case of national political parties, while as the same increases when taken the case of state level political parties. From 1957 to 2009 general elections there has been considerable growth among the women contestant with an average participation percentage of $42.76 \%$. While as the average participation percentage of women candidates of national parties remained at 35.07 
$\%$ and $22.16 \%$ for state level parties. Success percentage of women candidate of national parties has always been better to that of state level political parties with an average success percentage of $35.72 \%$ to that of $10.76 \%$. Success percentage among independents had been always abysmal with average success percentage of $0.29 \%$. At gross national level the average success percentage of women contestants during all the general elections remained at $15.03 \%$ and if we closely see the figures from 1951 to 2009 there is gradual decrease in the success percentage of women contestants. This decline can be owed to the fact that from each general election there is a steady increase in the number of women contestants contesting the elections. In 1957 election 22 women contestants represented electoral in Indian parliament, this number grew maximum of 59 women parliamentarians in the year 2009.

Table 5. Women Candidates Fielded by Major National Parties and their Performance.

\begin{tabular}{|c|c|c|c|c|c|c|c|c|c|c|c|c|c|}
\hline \multirow{2}{*}{ Year } & \multirow{2}{*}{$\begin{array}{l}\text { No of } \\
\text { Seats }\end{array}$} & \multicolumn{6}{|c|}{ Candidates fielded } & \multicolumn{6}{|c|}{ Candidates Elected \& Success Percentage } \\
\hline & & BJP & BSP & CPI & CPM & INC & ONP & $\begin{array}{l}\text { BJP } \\
(\%)\end{array}$ & $\begin{array}{l}\text { BSP } \\
\text { (\%) }\end{array}$ & $\begin{array}{l}\text { CPI } \\
(\%)\end{array}$ & $\begin{array}{c}\text { CPM } \\
\text { (\%) }\end{array}$ & $\begin{array}{r}\text { INC } \\
(\%)\end{array}$ & $\begin{array}{l}\text { ONP } \\
(\%)\end{array}$ \\
\hline$\ddot{\sigma}$ & \begin{tabular}{l}
$\stackrel{\infty}{\infty}$ \\
\multirow{\#}{\#}{}
\end{tabular} & ' & & 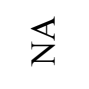 & ' & 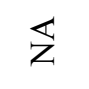 & 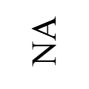 & & & $\overleftrightarrow{Z}$ & & 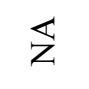 & 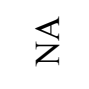 \\
\hline$\hat{n}$ & $\underset{\#}{\stackrel{Z}{\#}}$ & ' & & $\checkmark$ & ' & $\grave{\imath}$ & m & & & - & & 2 & 0 \\
\hline ర్ర & 范 & ' & & m & ' & $m$ & 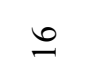 & ' & ' & - & ' & i & $\checkmark$ \\
\hline$\stackrel{5}{\circ}$ & तิ & ' & & m & - & m & $a$ & ' & ' & 0 & - & 2 & $\checkmark$ \\
\hline ลิ & $\frac{\infty}{n}$ & ' & & $\overleftrightarrow{z}$ & $\overleftrightarrow{z}$ & $\overleftrightarrow{z}$ & $\overleftrightarrow{z}$ & , & & $\overleftrightarrow{Z}$ & $\overleftrightarrow{z}$ & $\overleftrightarrow{z}$ & $\overleftrightarrow{z}$ \\
\hline 총 & 疋 & ' & & n & v & ป & $\Xi$ & ' & ' & $\neg$ & N & 6 & $\infty$ \\
\hline ஓి & तิ & ' & & $\sim$ & m & 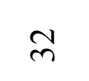 & q & ' & ' & - & $\sim$ & ¿ิ & $\nabla$ \\
\hline 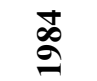 & $\frac{\Delta}{n}$ & $a$ & & $N$ & $m$ & ले & 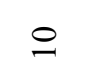 & 0 & & $\neg$ & - & m & 0 \\
\hline$\stackrel{\partial े}{\circ}$ & ते & 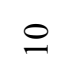 & & $\sim$ & in & in & $\unlhd$ & in & & - & $m$ & 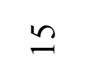 & $\sim$ \\
\hline $\bar{\sigma}$ & $\vec{\sim}$ & $\stackrel{\infty}{\sim}$ & & $n$ & $m$ & F & $\stackrel{\infty}{m}$ & $ㅇ$ & ' & $\neg$ & $N$ & $\stackrel{\text { }}{ }$ & $N$ \\
\hline ڤั & 年 & $\hat{\imath}$ & & $m$ & in & $\stackrel{q}{q}$ & $F$ & $\Xi$ & ' & - & - & 으. & $\nabla$ \\
\hline
\end{tabular}




\begin{tabular}{|c|c|c|c|c|c|c|c|c|c|c|c|c|c|}
\hline$\stackrel{\infty}{\sigma}$ & 年 & กี & 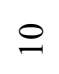 & 0 & $\infty$ & $\stackrel{\infty}{m}$ & $\cong$ & 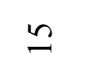 & - & $N$ & $m$ & 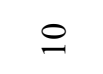 & 0 \\
\hline$\hat{\sigma}$ & $\stackrel{m}{n}$ & $\approx$ & $=$ & $\nabla$ & in & $\bar{n}$ & $\infty$ & 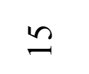 & - & - & $m$ & \pm & - \\
\hline 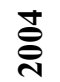 & 䚀 & in & ㄱ. & $N$ & $\infty$ & 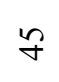 & in & 음 & - & 0 & in & $\simeq$ & $N$ \\
\hline ڤ્సે & $\stackrel{m}{n}$ & F & $\stackrel{\infty}{\sim}$ & $\nabla$ & 0 & $\mathscr{F}$ & $a$ & 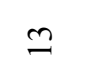 & $\nabla$ & 0 & - & $\tilde{\nu}$ & $N$ \\
\hline$\sum^{+\infty}$ & & 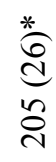 & $\underset{\sigma}{\stackrel{*}{\Xi}}$ & $\begin{array}{l}\stackrel{*}{(0} \\
F\end{array}$ & $\begin{array}{l}\stackrel{*}{\mathcal{J}} \\
\stackrel{f}{+}\end{array}$ & $\frac{\stackrel{*}{\stackrel{+}{+}}}{\frac{a}{n}}$ & 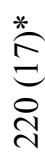 & 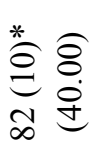 & 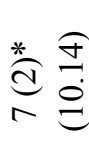 & $\begin{array}{l}\stackrel{*}{\Xi} \widehat{\delta} \\
= \\
= \\
=\end{array}$ & 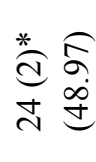 & 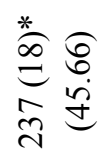 & 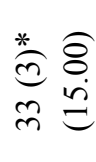 \\
\hline
\end{tabular}

Note-Average figures from candidates fielded have been rounded off either to next higher or to previous highest NA -Not Available

* -Average candidates fielded and elected.

Representation given to women candidates by each individual major national political party is equally an area of concern. Indian National Congress and Communist Party of India are the two main national political parties who have been at national scene since the inception of the electoral process in the country.

Excluding the data not availed for the year 1951 and 1971 INC and CPI has fielded women candidates from the very beginning which appears quite pleasing, but what concerns one of these political parties is the way they have show growth in field the women candidates during the subsequent elections which is just abysmal.

CPI has fielded a minimum of 2 women candidates and a maximum of 6 candidates with an average of 3 candidates during each general election. INC on average has fielded 40 women candidates during each general election, followed by BJP with 27 candidates, BSP 17, CPM 4 and other national parties 17 candidates.

In terms of success percentage of the total candidates fielded by major national political parties during all the general elections, CPM has recorded success percentage of $48.97 \%$, followed by INC with success percentage of $45.66 \%$, BJP $40.00 \%$, CPI $26.82 \%$, ONP $15 \%$ and BSP $10.14 \%$.

Similarly in terms of average candidates which succeeded during each general election include, INC (18), BJP (10), ONP (3), BSP \& CPM (2) each and CPI (1). 
Table 6. Scenario \& Representation of Women Candidates.

\begin{tabular}{|c|c|c|c|c|c|c|c|}
\hline \multirow{2}{*}{ Year } & \multirow{2}{*}{$\begin{array}{l}\text { Total } \\
\text { Seats }\end{array}$} & \multicolumn{2}{|c|}{ Candidate Fielded } & \multirow{2}{*}{$\begin{array}{c}\text { Elected \& } \\
\text { Success (\%) }\end{array}$} & \multirow{2}{*}{ Total Elector } & \multirow{2}{*}{$\begin{array}{c}\text { Voter } \\
\text { Turnout (\%) }\end{array}$} & \multirow{2}{*}{$\begin{array}{c}\text { Votes } \\
\text { Secured (\%) }\end{array}$} \\
\hline & & Total & Female (\%) & & & & \\
\hline $\bar{\Omega}$ & 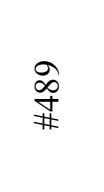 & $\underset{\infty}{\frac{1}{\infty}}$ & $\overleftrightarrow{Z}$ & $\overleftrightarrow{z}$ & 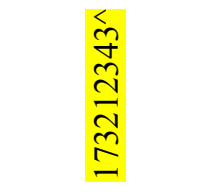 & 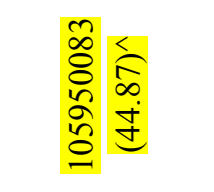 & $\overleftrightarrow{z}$ \\
\hline$\hat{2}$ & $\underset{\ddagger}{\stackrel{+}{\#}}$ & $\frac{\vec{a}}{a}$ & 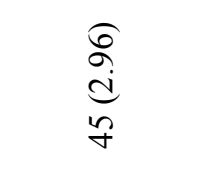 & 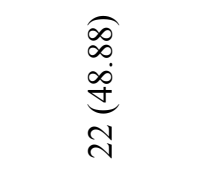 & $\begin{array}{l}2 \\
\frac{1}{2} \\
\tilde{\sigma} \\
\approx \\
\sigma\end{array}$ & 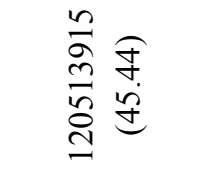 & 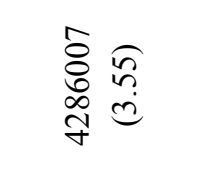 \\
\hline ర్ర & $\stackrel{d}{a}$ & $\stackrel{2}{2}$ & 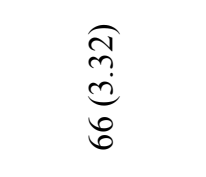 & $\begin{array}{l}\text { ఠ̊ } \\
\stackrel{0}{0} \\
\text { d } \\
\frac{n}{n}\end{array}$ & 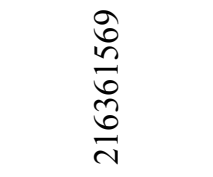 & 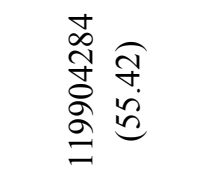 & 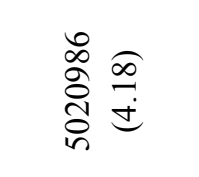 \\
\hline$\hat{\sigma}$ & $\stackrel{\text { సิ }}{n}$ & iे & 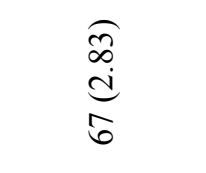 & 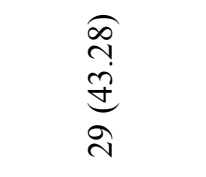 & 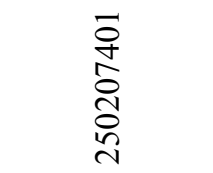 & 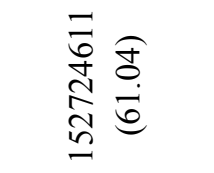 & 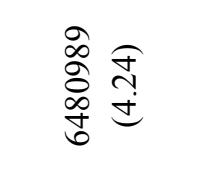 \\
\hline 종 & $\frac{\infty}{n}$ & 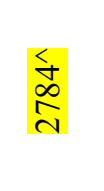 & $\overleftrightarrow{Z}$ & $\overleftrightarrow{z}$ & 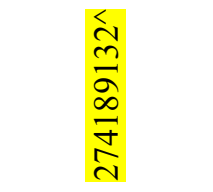 & 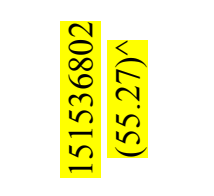 & $\overleftrightarrow{Z}$ \\
\hline 今ิ & 尔 & $\stackrel{\text { }}{\sim}$ & 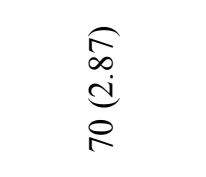 & $\begin{array}{l}\text { I } \\
\stackrel{\Delta}{d} \\
a\end{array}$ & 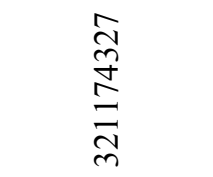 & 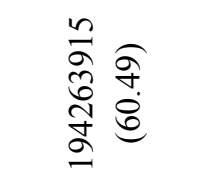 & 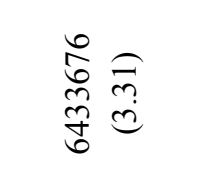 \\
\hline$\stackrel{\circ}{\circ}$ & ते & ते & $\begin{array}{l}\hat{g} \\
\dot{g} \\
\dot{m} \\
\stackrel{\Xi}{\Xi}\end{array}$ & $\begin{array}{l}\stackrel{\infty}{\infty} \\
\stackrel{n}{ٍ} \\
\stackrel{\infty}{\sim}\end{array}$ & 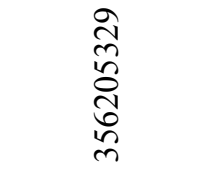 & 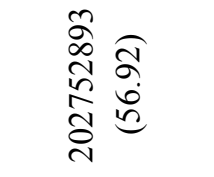 & 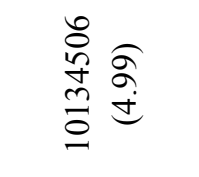 \\
\hline 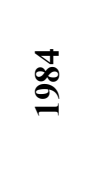 & $\frac{\pi}{n}$ & $\frac{N}{n}$ & 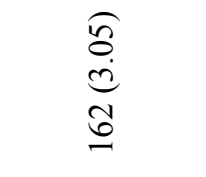 & 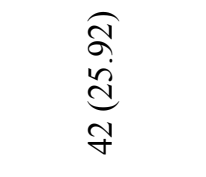 & 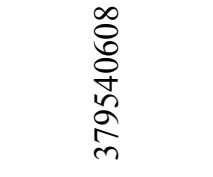 & 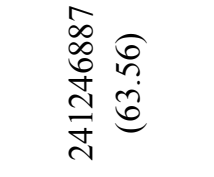 & 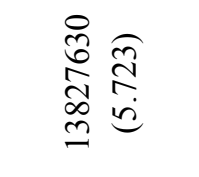 \\
\hline$\stackrel{\partial}{\varrho}$ & ते & $\frac{8}{6}$ & 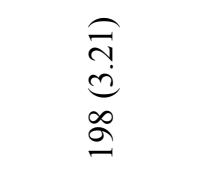 & 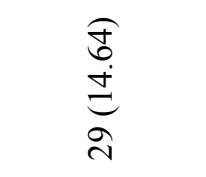 & 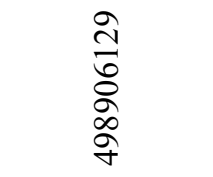 & 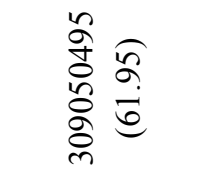 & 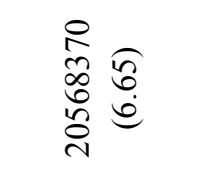 \\
\hline
\end{tabular}




\begin{tabular}{|c|c|c|c|c|c|c|c|}
\hline $\bar{\sigma}$ & $\vec{\sim}$ & $\begin{array}{l}\infty \\
\infty \\
\infty \\
\infty\end{array}$ & $\begin{array}{l}\sigma \\
i \\
0 \\
0 \\
0 \\
\infty\end{array}$ & $\begin{array}{l}\stackrel{f}{m} \\
\stackrel{\Xi}{\Xi} \\
m\end{array}$ & $\begin{array}{l}\vec{D} \\
\infty \\
0 \\
\infty \\
\infty \\
\infty \\
\sigma\end{array}$ & 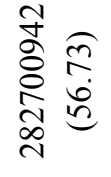 & 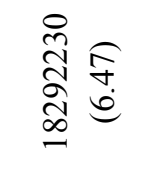 \\
\hline よ้ & $\stackrel{f}{n}$ & ஸे & $\begin{array}{l}\text { ते } \\
\stackrel{+}{n} \\
\text { nे }\end{array}$ & $\begin{array}{l}\widehat{\sigma} \\
\dot{6} \\
\dot{0} \\
+\end{array}$ & 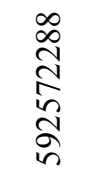 & 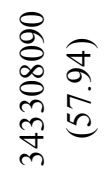 & 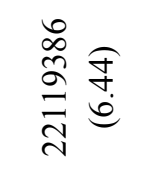 \\
\hline$\stackrel{2}{2}$ & $\stackrel{f}{n}$ & 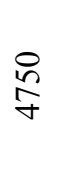 & 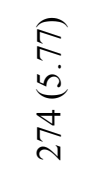 & $\begin{array}{l}\hat{\sigma} \\
\stackrel{d}{\sigma} \\
\underset{f}{\sigma}\end{array}$ & $\begin{array}{l}1 \\
\hat{a} \\
\infty \\
\infty \\
0 \\
0 \\
0\end{array}$ & 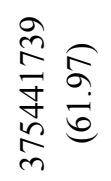 & 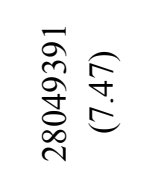 \\
\hline बे & $\stackrel{m}{n}$ & 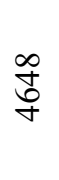 & 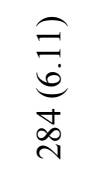 & 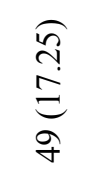 & 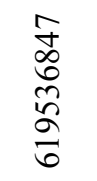 & 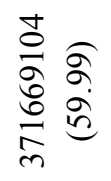 & 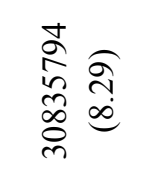 \\
\hline 芯 & $\stackrel{\text { f }}{n}$ & $\stackrel{m}{\tilde{f}}$ & $\begin{array}{l}\widehat{n} \\
\tilde{n} \\
\stackrel{n}{n} \\
\tilde{n}\end{array}$ & 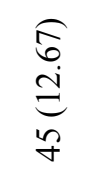 & 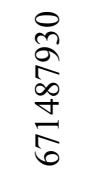 & 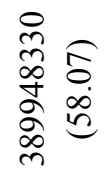 & 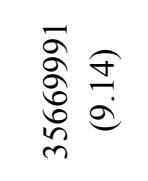 \\
\hline ڤ્े & 俩 & $\stackrel{?}{\stackrel{0}{0}}$ & 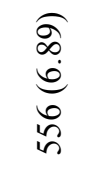 & $\begin{array}{l}\widehat{\sigma} \\
\stackrel{0}{0} \\
\text { in }\end{array}$ & $\begin{array}{l}\overrightarrow{0} \\
n \\
\infty \\
0 \\
0 \\
1\end{array}$ & $\begin{array}{l}\vec{\infty} \widehat{\sigma} \\
\stackrel{\sigma}{a} \\
\stackrel{\infty}{a} \\
\frac{\sigma}{\sigma}\end{array}$ & 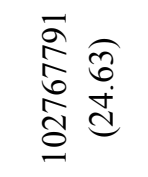 \\
\hline$\sum^{\infty}$ & & 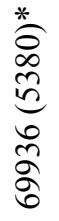 & 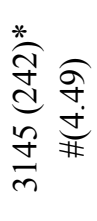 & 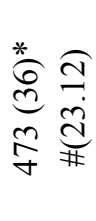 & 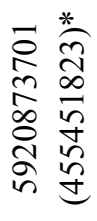 & 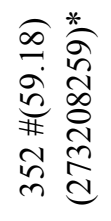 & 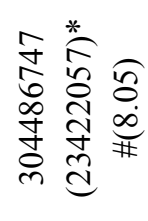 \\
\hline
\end{tabular}

$\wedge$-Data inadequately available as such excluded from computation NA -Not Available

* -Average candidates fielded and elected with average voters during each general election

\# Average percentage of candidates fielded and succeeded along with average voter turnout percentage

Of the total women candidates fielded, average success percentage of women candidates remained $23.12 \%$, which on average saw 36 female parliamentarians in each Lok Sabha so far. In the above tabulation attempt was also made to depict the the percentage of votes secured by women candidates during each general elections, accordingly a minimum of $3.31 \%$ votes went in to the kitty of women contestants during the 1977 elections and a maximum of 24.63 $\%$ during the 2009 elections. This is also for the fact that in 1977 only 70 women candidates were in fray while as in 2009 elections 556 women candidates tried their luck. So far during all the general elections women contestants have been able to seek an average vote of a mere 8.05 $\%$, which is far less when compared to votes sought by their male counter parts. 
Table 7. Gender Wise Status of Electors and Its Turnout.

\begin{tabular}{|c|c|c|c|c|c|}
\hline \multirow{2}{*}{ Year } & \multicolumn{2}{|c|}{ Total Electors } & \multicolumn{3}{|c|}{ Turnout and Percentage } \\
\hline & Total & Female & Total (\%) & Female (\%) & $\begin{array}{c}\text { Female voter } \\
\text { Turnout and (\%) }\end{array}$ \\
\hline 1951 & $173212343^{\wedge}$ & NA & $\begin{array}{c}105950083 \\
(44.87)^{\wedge}\end{array}$ & NA & \\
\hline 1957 & $193652179^{\wedge}$ & NA & $\begin{array}{c}120513915 \\
(45.44)^{\wedge}\end{array}$ & NA & \\
\hline 1962 & 216361569 & 102417335 & $\begin{array}{c}119904284 \\
(55.42)\end{array}$ & $\begin{array}{c}54102234 \\
(45.12)\end{array}$ & $\begin{array}{c}54102234 \\
(52.82)\end{array}$ \\
\hline 1967 & 250207401 & 120638797 & $\begin{array}{c}152724611 \\
(61.04)\end{array}$ & $\begin{array}{c}66264048 \\
(43.38)\end{array}$ & $\begin{array}{c}66264048 \\
(54.92)\end{array}$ \\
\hline 1971 & 274189132 & 130624303 & $\begin{array}{c}151536802 \\
(55.27)\end{array}$ & $\begin{array}{c}64153895 \\
(42.33)\end{array}$ & $\begin{array}{c}64153895 \\
(49.11)\end{array}$ \\
\hline 1977 & 321174327 & 154155176 & $\begin{array}{c}194263915 \\
(60.49)\end{array}$ & $\begin{array}{c}84653975 \\
(43.57)\end{array}$ & $\begin{array}{c}84653975 \\
(54.91)\end{array}$ \\
\hline 1980 & 356205329 & 170665890 & $\begin{array}{c}202752893 \\
(56.92)\end{array}$ & $\begin{array}{c}87395289 \\
(43.10)\end{array}$ & $\begin{array}{c}87395289 \\
(51.21)\end{array}$ \\
\hline 1984 & 379540608 & 182810109 & $\begin{array}{c}241246887 \\
(63.56)\end{array}$ & $\begin{array}{c}107123935 \\
(44.40)\end{array}$ & $\begin{array}{c}107123935 \\
(58.64)\end{array}$ \\
\hline 1989 & 498906129 & 236860987 & $\begin{array}{c}309050495 \\
(61.95)\end{array}$ & $\begin{array}{c}135759697 \\
(43.92)\end{array}$ & $\begin{array}{c}135759697 \\
(57.32)\end{array}$ \\
\hline 1991 & 498363801 & 236531302 & $\begin{array}{c}282700942 \\
(56.73)\end{array}$ & $\begin{array}{c}121454397 \\
(42.96)\end{array}$ & $\begin{array}{c}121454397 \\
(51.35)\end{array}$ \\
\hline 1996 & 592572288 & 282756512 & $\begin{array}{c}343308090 \\
(57.94)\end{array}$ & $\begin{array}{c}151028333 \\
(43.99)\end{array}$ & $\begin{array}{c}151028333 \\
(53.41)\end{array}$ \\
\hline 1998 & 605880192 & 289187403 & $\begin{array}{c}375441739 \\
(61.97)\end{array}$ & $\begin{array}{c}166844924 \\
(44.43)\end{array}$ & $\begin{array}{c}166844924 \\
(57.59)\end{array}$ \\
\hline 1999 & 619536847 & 295723180 & $\begin{array}{c}371669104 \\
(59.99)\end{array}$ & $\begin{array}{c}164539004 \\
(44.27)\end{array}$ & $\begin{array}{c}164539004 \\
(55.64)\end{array}$ \\
\hline 2004 & 671487930 & 321997066 & $\begin{array}{c}389948330 \\
(58.07)\end{array}$ & $\begin{array}{c}172714226 \\
(44.29)\end{array}$ & $\begin{array}{c}172714226 \\
(53.64)\end{array}$ \\
\hline 2009 & 716985101 & 342226300 & $\begin{array}{c}417159281 \\
(58.19)\end{array}$ & $\begin{array}{c}191028997 \\
(45.89)\end{array}$ & $\begin{array}{c}191028997 \\
(55.81)\end{array}$ \\
\hline Avg & $\begin{array}{c}6001410654 \\
(461646973) \\
*\end{array}$ & $\begin{array}{c}2866594360 \\
(220507258)^{*}\end{array}$ & $\begin{array}{c}3551707373 \\
\#(59.18) \\
(273208259)^{*}\end{array}$ & $\begin{array}{c}1567062954 \\
\#(45.10) \\
(120543304)^{*}\end{array}$ & $\begin{array}{c}1567062954 \\
\#(54.66) \\
(120543304)^{*}\end{array}$ \\
\hline
\end{tabular}

$\wedge$-Data inadequately available as such excluded from computation

NA- Not Available

* Average electors with average voter turnout

\# Average percentage voter turnout

Voter turnout is equally an area which needs to be addressed. There is a considerable difference when it comes to casting of vote by male or female electoral, compared to male electoral there has been always a lesser turn out of female voters. The lesser voter turnout trend among female electoral can be observed since the inception of electoral process of the country 
and can also be owed to the fact that Indian women most of the time remain occupied to domestic work, whereby she spends greater part with children and cattle and if able to spare any time then farming is on the cards. If we look at the average voter turnout percentage figures, almost $10 \%$ lesser turnout can be observed among women electoral to that of gross turn out percentage.

On average during all the general elections an average voter turnout has remained at $59.18 \%$ while as among women electoral it remained at $45.10 \%$. One more interesting fact which stands revealed in the above tabulation is about the turnout of female electors of the total registered women electors in the country during each individual election.

What is interesting to note here is, except for the year 1971 when female voter turnout remained below $50 \%$, the same remained above $50 \%$ during rest of the general elections. And the average female voter turnout during all the general elections remained at $54.66 \%$ which is quite convincing.

Table 8. Distribution of Vote Share among Woman Contestants.

\begin{tabular}{|c|c|c|c|c|c|c|}
\hline \multirow{2}{*}{ Year } & \multirow{2}{*}{$\begin{array}{l}\text { Total } \\
\text { Seats }\end{array}$} & \multirow{2}{*}{ WCF } & \multicolumn{4}{|c|}{ Vote Share \& Percentage } \\
\hline & & & NP (\%) & SP (\%) & IN (\%) & Total \\
\hline 1951 & 401 & NA & NA & NA & NA & NA \\
\hline 1957 & 403 & 45 & $3963166(92.46)^{\wedge}$ & NA & NA & $4286007^{\wedge}$ \\
\hline 1962 & 494 & 66 & NA & NA & NA & $5020986^{\wedge}$ \\
\hline 1967 & 520 & 67 & $5676183(87.58)$ & $541472(8.35)$ & $263334(4.06)$ & 6480989 \\
\hline 1971 & 518 & NA & NA & NA & NA & NA \\
\hline 1977 & 542 & 70 & NA & NA & NA & $6433676^{\wedge}$ \\
\hline 1980 & 529 & 143 & $9252643(91.29)$ & $512914(5.06)$ & $368949(3.64)$ & 10134506 \\
\hline 1984 & 514 & 162 & NA & NA & NA & $13827630^{\wedge}$ \\
\hline 1989 & 529 & 198 & $18095726(87.97)$ & $2253236(10.95)$ & 219408 (1.06) & 20568370 \\
\hline 1991 & 521 & 326 & NA & NA & NA & $18292230^{\wedge}$ \\
\hline 1996 & 543 & 599 & $18809959(85.03)$ & $1997404(9.03)$ & $1312023(5.93)$ & 22119386 \\
\hline 1998 & 543 & 274 & $18921101(67.45)$ & 8344038 (29.74) & $784252(2.79)$ & 28049391 \\
\hline 1999 & 543 & 284 & $20598951(66.80)$ & $9417402(30.54)$ & $819441(2.65)$ & 30835794 \\
\hline 2004 & 543 & 355 & $23755420(66.59)$ & $11169663(31.31)$ & 744908 (2.08) & 35669991 \\
\hline 2009 & 543 & 556 & $25728512(25.03)$ & 75966609 (73.92) & $1072670(1.04)$ & 102767791 \\
\hline Avg & & & $140838495(74.46)$ & $110202738(24.86)$ & $5584985(2.90)$ & 304486747 \\
\hline
\end{tabular}

NP -National Parties, SP- State Parties, IN- Independents, NA-Not Available

$\wedge$-Data inadequately available as such excluded from computation 
Data of votes obtained by women contestants during all the general elections is not completely available, so the analysis in the above tabulation has been made only by considering that data which is in all the required fields under study. However, wherever the data is available has been reflected for information. If we see at gross national level a maximum of $74.46 \%$ vote share has gone to female candidates fielded by national parties, followed by $24.86 \%$ vote share to candidates of state parties and the minimum $2.90 \%$ to independents. National parties had a major share of vote percentage during each individual election except for the year 2009 when $73.92 \%$ vote share obtained by female contestants went to candidates fielded by state political parties. Performance of Independent female candidates had been always abysmal during all the elections and this gets better corroborated by the fact that on the whole $2.90 \%$ votes were obtained by independent female candidates during all the general elections.

Table 9. Percentage of votes Obtained by Women Candidates fielded by Major National Parties.

\begin{tabular}{|c|c|c|c|c|c|c|c|c|c|}
\hline \multirow{2}{*}{ Year } & \multirow{2}{*}{$\begin{array}{l}\text { No of } \\
\text { Seats }\end{array}$} & \multicolumn{8}{|c|}{ Major National Parties } \\
\hline & & BJP & BSP & CPI & CPM & INC & ONP & SP & IND \\
\hline 1951 & \#489 & - & - & NA & - & NA & NA & NA & NA \\
\hline 1957 & \#494 & - & - & 10.21 & - & 76.37 & 5.86 & NA & NA \\
\hline 1962 & 494 & - & - & 6.01 & - & 68.16 & 17.42 & NA & NA \\
\hline 1967 & 520 & - & - & 5.13 & 2.72 & 63.97 & 15.74 & 8.35 & 4.06 \\
\hline 1971 & 518 & - & - & NA & NA & NA & NA & NA & NA \\
\hline 1977 & 542 & - & - & 4.79 & 6.55 & 39.64 & 41.62 & 5.48 & 1.89 \\
\hline 1980 & 529 & - & - & 5.05 & 5.96 & 51.62 & 28.65 & 5.06 & 3.64 \\
\hline 1984 & 514 & 4.97 & - & 3.64 & 4.47 & 68.68 & 7.43 & NA & NA \\
\hline 1989 & 529 & 10.92 & - & 3.67 & 8.43 & 58.88 & 6.06 & 10.95 & 1.06 \\
\hline 1991 & 521 & 20.67 & - & 5.41 & 4.38 & 51.11 & 6.02 & NA & NA \\
\hline 1996 & 543 & 19.54 & - & 2.44 & 7.95 & 43.67 & 11.41 & 9.03 & 5.93 \\
\hline 1998 & 543 & 25.39 & 1.66 & 3.05 & 8.99 & 26.45 & 2.05 & 29.74 & 2.79 \\
\hline 1999 & 543 & 22.27 & 2.10 & 1.49 & 4.27 & 35.10 & 1.55 & 30.54 & 2.65 \\
\hline 2004 & 543 & 19.45 & 3.03 & 0.82 & 7.65 & 33.42 & 2.20 & 31.31 & 2.08 \\
\hline 2009 & 543 & 7.74 & 1.50 & 0.07 & 1.63 & 12.45 & 1.61 & 73.92 & 1.04 \\
\hline Avg & - & 16.36 & 2.07 & 3.98 & 5.72 & 48.42 & 11.35 & 22.70 & 2.79 \\
\hline
\end{tabular}

BJP -Bharitya Janta Party, BSP - Bhaujan Samja Party,

CPI -Communist Party of India, CPM -Communist Party of India (Marxist),

INC -Indian National Congress, ONP -Other National Parties,

SP -State Parties, IND -Independents

NA -Not Available 
Performance of women candidates at party level apart from winning the seats also gets reflected by the percentage of votes obtained by women candidates fielded by a particular political party. Accordingly in the above tabulation attempt has been made to assess the percentage of votes obtained by female candidates fielded by some of the prominent national parties. Female contestants of INC on average during all the general election has secured a maximum of $48.42 \%$ votes, followed by BJP $16.36 \%$, CPM $5.72 \%$, CPI $3.98 \%$ and BSP $2.07 \%$. Other national parties together have secured $11.35 \%$ votes and the state level political parties together have secured $22.70 \%$ votes. Independent women contestants again have an abysmal $2.79 \%$ of vote share percentage.

Table 10. Deposits Forfeited by Women Candidates.

\begin{tabular}{|c|c|c|c|c|c|c|c|c|}
\hline \multirow{2}{*}{ Year } & \multicolumn{3}{|c|}{ Women Candidates Fielded } & \multicolumn{3}{|c|}{ Women Candidates Forfeited Deposits (\%) } \\
\cline { 2 - 9 } & NP & SP & IN & Total & NP (\%) & SP (\%) & IN (\%) & Total (\%) \\
\hline $\mathbf{1 9 5 1}$ & NA & NA & NA & NA & NA & NA & NA & NA \\
\hline $\mathbf{1 9 5 7}$ & 34 & 2 & 9 & 45 & $1(2.94)$ & $0(0)$ & $7(77.77)$ & $8(17.77)$ \\
\hline $\mathbf{1 9 6 2}$ & 52 & 6 & 8 & 66 & $9(17.30)$ & $3(50.00)$ & $7(87.50)$ & $19(28.78)$ \\
\hline $\mathbf{1 9 6 7}$ & 50 & 7 & 10 & 67 & $3(6.00)$ & $3(42.85)$ & $8(80.00)$ & $14(20.89)$ \\
\hline $\mathbf{1 9 7 1}$ & NA & NA & NA & NA & NA & NA & NA & NA \\
\hline $\mathbf{1 9 7 7}$ & 41 & 5 & 24 & 70 & $4(9.75)$ & $3(60.00)$ & $24(100)$ & $31(44.28)$ \\
\hline $\mathbf{1 9 8 0}$ & 77 & 5 & 61 & 143 & $18(23.37)$ & $1(20.00)$ & $60(98.36)$ & $79(55.24)$ \\
\hline $\mathbf{1 9 8 4}$ & 63 & 5 & 94 & 162 & $10(15.87)$ & $1(20.00)$ & $92(97.87)$ & $103(63.58)$ \\
\hline $\mathbf{1 9 8 9}$ & 87 & 29 & 82 & 198 & $12(13.79)$ & $21(72.41)$ & $82(100)$ & $115(58.08)$ \\
\hline $\mathbf{1 9 9 1}$ & 119 & 53 & 154 & 326 & $50(42.01)$ & $45(84.90)$ & $154(100)$ & $249(76.38)$ \\
\hline $\mathbf{1 9 9 6}$ & 125 & 50 & 424 & 599 & $54(43.2)$ & $43(86.00)$ & $421(99.29)$ & $518(86.47)$ \\
\hline $\mathbf{1 9 9 8}$ & 107 & 90 & 77 & 274 & $45(42.05)$ & $64(71.11)$ & $75(97.40)$ & $184(67.15)$ \\
\hline $\mathbf{1 9 9 9}$ & 104 & 102 & 78 & 284 & $35(33.65)$ & $72(70.58)$ & $76(97.40)$ & $183(64.43)$ \\
\hline $\mathbf{2 0 0 4}$ & 110 & 128 & 117 & 355 & $29(26.36)$ & $93(72.65)$ & $117(100)$ & $239(67.32)$ \\
\hline $\mathbf{2 0 0 9}$ & 134 & 215 & 207 & 556 & $52(38.80)$ & $184(85.58)$ & $205(99.03)$ & $441(79.31$ \\
\hline $\mathbf{A v g}$ & 1103 & 697 & 1345 & 3145 & $322(29.19)$ & $533(76.47)$ & $1328(98.73)$ & $2183(69.41)$ \\
$(85)^{*}$ & $(54)^{*}$ & $(103)^{*}$ & $(242)^{*}$ & $(25)^{*}$ & $(41)^{*}$ & $(102)^{*}$ & $(168)^{*}$ \\
\hline $\mathbf{N P}$ & & 53 & & & \\
\hline
\end{tabular}

NP-National Parties, SP- State Parties, IN- Independents, NA-Not Available

*-Average candidates fielded with average candidates who forfeited their deposits

^-Data inadequately available but excluded from computation

Forfeiture of deposits of the candidates fielded is equally a parameter to assess the presence of a particular political party among masses. Since fielding of candidates on the basis of sex can make a profound impact on assessing the presence of a particular political party as 
most of the electors may not cast their vote to a political party for fielding a women contestant, if their mind is gender biased. Given this fact the above tabulation is an attempt to see how far the women candidates have forfeited their deposits keeping in view their affiliation to national party, state party or as an independent candidate. Looking at the gross aggregate figures, of the total women candidates fielded by national parties $29.19 \%$ forfeited their deposits, $76.47 \%$ of state political parties followed the same suit, and $98.73 \%$ independent contestants. On the whole at gross national level of the total women contestants fielded irrespective of their party affiliation $69.41 \%$ contestants have forfeited their deposits. During the earlier elections, a lesser percentage of women candidates from national parties forfeited their deposits, but as we move down the table, this percentage gradually increases, and this is for the fact that greater number of women candidates started contesting elections, which as a result contributed to the forfeiture of their deposits in greater number.

Table 11. Percentage of Women Candidates of Major National Parties Who Forfeited Deposits.

\begin{tabular}{|c|c|c|c|c|c|c|c|c|c|c|c|c|}
\hline \multirow[b]{2}{*}{ Year } & \multicolumn{6}{|c|}{ Candidates fielded } & \multicolumn{6}{|c|}{ Candidates Forfeited Deposits \& \%age } \\
\hline & $\hat{\theta}$ & 宓 & $\overline{\mathbf{U}}$ & $\sum_{i}$ & $\underline{Z}$ & $\frac{\bar{z}}{0}$ & 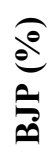 & $\underbrace{\hat{\theta}}_{\hat{\theta}}$ & $\frac{\hat{e}}{0}$ & $\underbrace{e}_{i}$ & 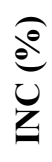 & $\frac{\underbrace{o}}{\hat{z}^{\circ}}$ \\
\hline$\overline{\check{n}}$ & ' & ' & $\overleftrightarrow{z}$ & ' & $\overleftrightarrow{z}$ & $\overleftrightarrow{z}$ & & ' & $\overleftrightarrow{z}$ & & $\overleftrightarrow{z}$ & $\overleftrightarrow{z}$ \\
\hline$\hat{n}$ & ' & ' & $\nabla$ & ' & $\hat{\imath}$ & $m$ & & ' & $\begin{array}{l}8 \\
\stackrel{d}{d} \\
\text { id }\end{array}$ & & $\stackrel{\hat{e}}{o}$ & อ़ \\
\hline گ్ర & ' & ' & $n$ & ' & $\stackrel{m}{m}$ & $\mathscr{0}$ & & ' & $\begin{array}{l}\overparen{n} \\
\tilde{n} \\
\stackrel{0}{0} \\
-1\end{array}$ & & $\begin{array}{l}\widehat{\sigma} \\
\stackrel{0}{0} \\
-1\end{array}$ & 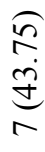 \\
\hline$\stackrel{8}{2}$ & ' & ' & $n$ & - & $\hat{n}$ & $a$ & & ' & $\stackrel{\mathfrak{c}}{0}$ & $\stackrel{\varrho}{0}$ & $\begin{array}{l}\widehat{2} \\
\stackrel{i}{i} \\
-1\end{array}$ & $\begin{array}{l}\Xi \\
\Xi\end{array}$ \\
\hline 5 & ' & ' & $\overleftrightarrow{z}$ & $\overleftrightarrow{z}$ & $\overleftrightarrow{z}$ & $\overleftrightarrow{z}$ & & ' & $\overleftrightarrow{z}$ & $\overleftrightarrow{z}$ & $\overleftrightarrow{z}$ & $\overleftrightarrow{Z}$ \\
\hline ลิ & ' & ' & $n$ & $N$ & तี & \pm & & ' & $\begin{array}{l}0 \\
b \\
0 \\
0 \\
0\end{array}$ & $\stackrel{\varrho}{0}$ & $\begin{array}{l}\hat{\sigma} \\
\stackrel{a}{0} \\
\stackrel{0}{v}\end{array}$ & $\stackrel{\varrho}{0}$ \\
\hline
\end{tabular}




\begin{tabular}{|c|c|c|c|c|c|c|c|c|c|c|c|c|}
\hline ஜ̊ & ' & ' & $N$ & $m$ & กี & \& & & ' & $\stackrel{\hat{e}}{0}$ & $\begin{array}{c}\text { } \\
\stackrel{0}{0} \\
\stackrel{0}{0}\end{array}$ & $\begin{array}{l}\overparen{\Im} \\
\stackrel{0}{-}\end{array}$ & $\begin{array}{l}\widehat{g} \\
\stackrel{8}{+} \\
\text { o }\end{array}$ \\
\hline 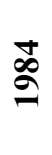 & $a$ & ' & $N$ & $m$ & શે & 으 & $\begin{array}{l}\tilde{n} \\
n \\
n \\
n \\
n\end{array}$ & ' & $\stackrel{\hat{e}}{0}$ & $\begin{array}{l}\tilde{n} \\
\tilde{n} \\
\tilde{d} \\
=\end{array}$ & $\stackrel{\varrho}{o}$ & $\begin{array}{l}\stackrel{\partial}{8} \\
\stackrel{8}{+} \\
\dot{\sigma}\end{array}$ \\
\hline$\stackrel{\not े}{\sigma}$ & 으 & ' & $\sim$ & in & in & $\Xi$ & $\begin{array}{l}\widehat{\delta} \\
\dot{0} \\
0 \\
m \\
m\end{array}$ & ' & $\stackrel{\hat{\rho}}{0}$ & $\stackrel{\varrho}{0}$ & $\stackrel{\hat{\theta}}{0}$ & 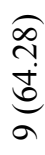 \\
\hline $\bar{\sigma}$ & $\stackrel{\infty}{\sim}$ & ' & $n$ & $n$ & f & $\underset{n}{\infty}$ & $\begin{array}{l}\overparen{J} \\
\stackrel{\sim}{d} \\
\stackrel{d}{\sigma} \\
\sigma\end{array}$ & ' & $\stackrel{\widehat{e}}{0}$ & $\stackrel{\widehat{e}}{0}$ & 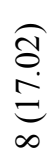 & 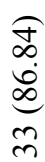 \\
\hline 。 & $\widehat{\imath}$ & ' & $n$ & $n$ & $\stackrel{q}{q}$ & $F$ & 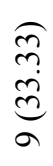 & ' & 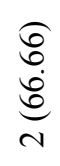 & $\stackrel{\varrho}{\hat{e}}$ & $\begin{array}{l}\overparen{f} \\
\stackrel{J}{d} \\
= \\
=\end{array}$ & 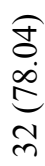 \\
\hline$\stackrel{\infty}{\circ}$ & กี & 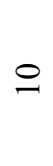 & 0 & $\infty$ & $\underset{\substack{\infty \\
m}}{ }$ & $\underline{\sim}$ & $\begin{array}{l}\overparen{d} \\
\infty \\
\underset{d}{d} \\
a\end{array}$ & $\begin{array}{l}\stackrel{\delta}{0} \\
\underset{\infty}{\infty} \\
\underset{\infty}{\infty}\end{array}$ & $\begin{array}{l}\overparen{8} \\
\stackrel{0}{0} \\
\stackrel{0}{0} \\
m\end{array}$ & 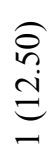 & 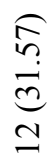 & 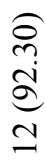 \\
\hline & $\approx$ & $\Xi$ & $\nabla$ & $n$ & $\vec{n}$ & $\infty$ & 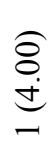 & 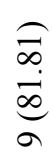 & $\begin{array}{l}\overparen{8} \\
i \\
i \\
m\end{array}$ & $\begin{array}{l}\text { } \\
\stackrel{8}{0} \\
\underset{\sim}{+}\end{array}$ & $\begin{array}{l}\overparen{a} \\
\stackrel{d}{d} \\
\stackrel{m}{=}\end{array}$ & $\begin{array}{l}\text { } \\
\stackrel{n}{n} \\
\stackrel{\infty}{0} \\
r\end{array}$ \\
\hline త్రి & ల్ల & 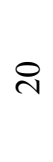 & $\sim$ & $\infty$ & f & $n$ & 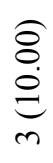 & $\begin{array}{l}\hat{8} \\
\dot{8} \\
\underbrace{} \\
0\end{array}$ & $\begin{array}{l}\overparen{8} \\
\stackrel{8}{8} \\
\stackrel{0}{0} \\
-\end{array}$ & 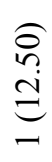 & $\begin{array}{l}\exists \\
\Xi \\
\Xi\end{array}$ & $\begin{array}{l}\text { } \\
\stackrel{8}{8} \\
\text { : }\end{array}$ \\
\hline હे & 寸 & $\stackrel{\infty}{\sim}$ & $\nabla$ & 0 & $\mathscr{f}$ & $a$ & $\begin{array}{l}\overrightarrow{8} \\
8 \\
0\end{array}$ & 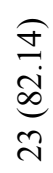 & $\underset{\forall}{\stackrel{\ominus}{\ominus}}$ & $\stackrel{m}{m}$ & $\begin{array}{l}\hat{\sigma} \\
\hat{\sigma}\end{array}$ & 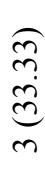 \\
\hline
\end{tabular}




\begin{tabular}{|c|c|c|c|c|c|c|c|c|c|c|c|c|}
\hline$\sum^{+\infty}$ & 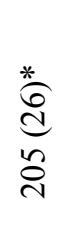 & $\begin{array}{l}\stackrel{*}{E} \\
\text { E }\end{array}$ & $\begin{array}{l}\stackrel{*}{(0)} \\
F\end{array}$ & $\begin{array}{l}\stackrel{*}{\mathscr{J}} \\
\stackrel{g}{f}\end{array}$ & $\begin{array}{l}\stackrel{*}{\stackrel{+}{+}} \\
\frac{\sigma}{n}\end{array}$ & 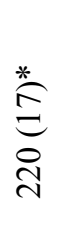 & 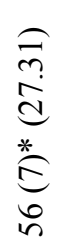 & 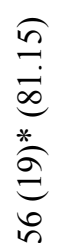 & 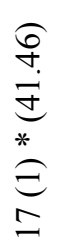 & 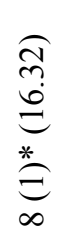 & 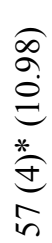 & 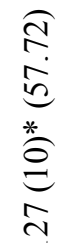 \\
\hline
\end{tabular}

BJP -Bharitya Janta Party, BSP - Bhaujan Samja Party, CPI -Communist Party of India, CPM -Communist Party of India (Marxist), INC -Indian National Congress, ONP -Other National Parties, SP-State Parties, IND -Independents NA -Not Available, * -Average candidates fielded with average candidates who forfeited their deposits Note -Average figures from candidates fielded have been rounded off either to next higher or to previous highest

Forfeiture of deposits of the contestants is used for SWOT analysis by most of the political parties. It is always important to know about the ones Strengths, Weaknesses, and to keep an eye over the Opportunities and Threats in the market. If we see the overall forfeiture of deposits of the women candidates fielded by major national political parties we can see a maximum $81.15 \%$ contestants are from BSP, $41.46 \%$ from CPI, $27.31 \%$ from BJP, $16.32 \%$ from CPM, $10.57 \%$ form INC and $57.72 \%$ from ONP. The interesting aspect about the forfeiture of deposits by women contestants of leading national parties like INC and BJP is far less when compared to other national parties and this is only for the fact that both these parties are very selective in fielding their women candidates, as they mostly go with those women candidates which enjoy some prominence and do have some credibility in society. While as when taken the case of other parties they mostly do so for the sake of women representation and winning and losing is merely matter of chance for them.

\section{CONCLUSIONS}

An Indian woman has shown her mettle in almost every sphere of human activity and politics is no exception to her, this has already been proven by the women who have made it to the parliament. Introduction of women's reservation bill can be considered as a giant-leap in the history of Indian parliament which will ensure greater participation of women in the elected office and obviously will ensure better chances for women across the country to grow more confident and more independent. Political reservation is equally going to boost the other sectors for women as this will prove more s psychological victory for them.

India as a democracy during past 15 general elections has grown in many ways. More than 2000 small and large parties are registered with the Election Commission of India, to ensure deprived sections of the society have representation in parliament, constitutional provisions were made. But when it comes to the women representation in Indian polity then the figures are very discouraging and so far nothing like reservation exists for them. Although women had been representing general elections of India from the very beginning but the way there should have been some significant growth among the women candidates contesting elections over a period of time has been missing. Nobody could so far crack the story as what is it that has not let Indian women to succeed in polity. It is not that Indian women is still reeling under the age old tradition of conservatism, she is modern, successful, independent, selfsufficient with ample economic empowerment, but when it comes to political empowerment 
then we must accept this fact that Indian women is still reeling behind at this front when compared to women of other countries.

To empower Indian women politically, women reservation bill seems to be the only way out, but this will ensure political empowerment of women is a big question, as people have already started dubbing this reservation more of women appeasement bill rather proving of any worth on ground. There is every possibility that women may be pushed for decision making against their wishes once they are affiliated to any political party, so simply will act as a member in the hands of party, where she may not go against the interests and wishes of a party.

Well one can say, it is too early and premature to grow pessimistic about the bill, when there is still lot yet to come. What is good about the bill is, that it has already been introduced by the Govt of India where it has sought the approval of the upper house of the parliament and is almost bound to be through in the lower house of the parliament once tabled, the way most of the political parties in the country are backing it. But the political hypocrisy of the Indian polity is not concealed to anybody especially after going through the present study. The leading political parties of India who had been crying hard for the women's reservation have actually nowhere given fair representation to women candidates till 2009 general elections. Knowing very well that road to parliament for Indian women is very tough so the only solution to make it easy appeared by making it more constitutional. Still the interesting aspect is to witness the representation which will be given to women candidates by major political parties of the country in the 2014 general elections.

\section{References}

[1] United Nations entity for Gender Equality and the empowerment of women. Retrieved October 27, 2013 from: http://www.un.org/womenwatch/daw/cedaw/

[2] Geraldine Forbes (1979). Votes for Women: The demand for Women's franchise in India, in Vina Mazumdar (Ed), Symbols of Power: Studies on the Political Status of Women in India, Bombay.

[3] Ministry of Home affaris, Govt of India. available at: http://www.censusindia.gov.in/Census_And_You/index.aspx

[4] Geo-Hack-India. (n.d). Retrieved July 13, 2013 from: http://tools.wmflabs.org/geohack/geohack.php?pagename $=$ India\&params $=28$ _36.8_N_7 7_12.5_E_type:country

[5] Indian Parliament. (n.d). Accessed on August 2, 2013. Available at: http://www.parliamentofindia.nic.in/

[6] Election Commissioner of India. (n.d). Retrieved July 13, 2013 from: http://eci.gov.in/eci_main1/index.aspx

[7] Ibid.

[8] Ibid.

[9] Fox Richard L., et al., Gendered Perceptions and Political Candidacies: A Central Barrier to Women's Equality in Electoral Politics. American Journal of Political Science 55 (1) 2011) 59-73. 
[10] United Nations Development Programme (2002). Human Development Report 2002, New York: Oxford University Press

[11] Pacific Institute of Advanced Studies in Development and Governance. (2005). REPORT ON THE COOK ISLANDS PARLIAMENTARY ELECTIONS OBSERVATION. (2004). The University of the South Pacific Serving the Cook Islands, Fiji, Kiribati, Marshall Islands, Nauru, Niue, Samoa, Solomon Islands, Tokelau, Tonga, Tuvalu, Vanuatu

[12] Phillips A. (ed) (1998). Feminism and Politics, Oxford: Oxford University Press

[13] Carroll S. J. (ed.) (2001). The Impact of Women in Public Office, Indiana: University of Indiana Press.

[14] Pitkin H. (1967). The Concept of Representation, Berkeley: University of California Press.

[15] Inglehart R., Norris P. (2003). Rising Tide: Gender Equality and Cultural Change, New York: Cambridge University Press.

[16] Bergqvist C., Borchorst A., Christensen A., Ramstedt-Silén V., Raaum N. C., Styrkársdóttir A. (eds.) (1999) Equal Democracies? Gender and Politics in the Nordic Countries, Olso: Scandinavian University Press.

[17] Mhatre Minal (2009). Women in Electoral Politics: A Case Study of Women's Political Participation in Maharashtra

[18] Reynolds A., Reserved seats in national legislatures, Legislative Studies Quarterly 30(2) 2005) 301-310.

[19] Tinker I., Quotas for women in elected legislatures: do they really empower women? Womens Studies International Forum 27(5-6) 2004) 531-546. 